\title{
A review of the online prognositc model predict using the POSH cohort (women aged $\leq 40$ years at breast cancer diagnosis)
}

\author{
Tom Maishman ${ }^{1 *}$, Ellen Copson ${ }^{1}$, Louise Stanton ${ }^{1}$, Sue Gerty ${ }^{1}$, Ed Dicks², Lorraine Durcan ${ }^{1}$, Gordon Wishart ${ }^{3}$, \\ Paul Pharoah², Diana Eccles ${ }^{3}$
}

From 3rd International Clinical Trials Methodology Conference

Glasgow, UK. 16-17 November 2015

\section{Introduction}

Breast cancer is the most common cancer women in the UK, with approximately 50,000 new cases each year. PREDICT (http://www.predict.nhs.uk) is an online prognostic tool developed to help determine the best available treatment and long-term outcome for early breast cancer. This study was conducted to establish how well PREDICT performs in estimating survival in a large cohort of younger women (aged $\leq 40$ years) recruited to the $\mathrm{POSH}$ study.

\section{Methods}

The UK POSH cohort includes data from 3000 women aged $\leq 40$ years at breast cancer diagnosis. Study endpoints were overall- and breast cancer specific-survival at 5-,8-, and 10-years. Evaluation of PREDICT included model discrimination and comparison of the number of predicted versus observed events.

\section{Results}

PREDICT provided accurate long term (8- and 10-year) survival estimates for younger women. However, short term (5-year) estimates were less accurate, with the tool overestimating survival by $25 \%$, and by $56 \%$ for patients with ER positive tumours. PREDICT also underestimated survival at 5-years for patients with ER negative tumours.

\section{Conclusions}

PREDICT is a user-friendly and reliable tool for providing accurate long-term survival estimates for younger women with breast cancer. However, the model requires further calibration for more accurate short-term estimates.

${ }^{1}$ Cancer Sciences Academic Unit and University of Southampton Clinical Trials Unit, Southampton, UK

Full list of author information is available at the end of the article
Prediction in the short-term may be most relevant for the increasing number of women considering risk-reducing bilateral mastectomy.

\section{Acknowledgements}

Funding for data collection/analysis of the POSH study by CRUK (grants A7572, A11699, C1275/A15956). Study sponsored by UHS NHS Foundation Trust. We also thank the NIHR NCRN for supporting patient recruitment and all participating patients.

Authors' details

${ }^{1}$ Cancer Sciences Academic Unit and University of Southampton Clinical Trials Unit, Southampton, UK. ${ }^{2}$ Department of Oncology, University of Cambridge, Cambridge, UK. ${ }^{3}$ Faculty of Medical Science, Anglia Ruskin University, Cambridge, UK.

Published: 16 November 2015

doi:10.1186/1745-6215-16-S2-P36

Cite this article as: Maishman et al:: A review of the online prognositc model predict using the POSH cohort (women aged $\leq 40$ years at breast cancer diagnosis). Trials 2015 16(Suppl 2):P36.

Submit your next manuscript to BioMed Central and take full advantage of:

- Convenient online submission

- Thorough peer review

- No space constraints or color figure charges

- Immediate publication on acceptance

- Inclusion in PubMed, CAS, Scopus and Google Scholar

- Research which is freely available for redistribution 